\title{
Gas Chromatography-Mass Spectrometric Analysis of a Counterfeit Sildenafil product and its Potential Hepatotoxicity in Mice.
}

\author{
Asmaa M. Ahmed ${ }^{1}$, Nora Z. Abdellah ${ }^{2 *}$, Eman S. Shaltout ${ }^{2}$
}

\begin{tabular}{|c|c|}
\hline & ABSTRACT \\
\hline $\begin{array}{l}\text { KEYWORDS } \\
\text { Illicit erection enhancers, } \\
\text { Anthraquinone, } \\
\text { Counterfeit sildenafil, } \\
\text { Hepatotoxicity, } \\
\text { Sildenafil citrate. }\end{array}$ & $\begin{array}{l}\text { The market of illicit erection/potency enhancers has grown significantly in the } \\
\text { last decade. Some of those products lack any data about active ingredients, have } \\
\text { dosage mislabeling or claim to contain only natural substances. The aim of this } \\
\text { study is to elucidate the various contents and concentration of sildenafil in a cheap } \\
\text { illicit erection enhancer tablets available in local markets and to evaluate its } \\
\text { potential toxic effects on the liver. An illicit oral preparation (tablet form), sold in } \\
\text { local market as an erection enhancer and claim to contain } 130 \mathrm{mg} \text { of sildenafil } \\
\text { citrate/ tablet, was analyzed by Gas Chromatography-Mass Spectrometry (GC- } \\
\text { MS). The same preparation was dissolved in distilled water and administered per } \\
\text { oral route in two doses (8.13 } \mathrm{mg} / \mathrm{Kg} \text { / day and } 50 \mathrm{mg} / \mathrm{kg} / \mathrm{day} \text { ) for } 8 \text { weeks to male } \\
\text { mice to investigate its effects on hepatic tissue. A control group was given distilled } \\
\text { water only. Analysis of the tablets demonstrated several ingredients including the } \\
\text { potential hepatotoxic 1-Bromo-2,4-dimethoxyanthrquinone, and N- } \\
\text { Trichloroacetyl-tryptamine with no traces for sildenafil citrate. The study showed } \\
\text { that the preparation caused dose dependent histopathologic changes in liver of } \\
\text { mice. These changes included lobular inflammation, kupffer cell hyperplasia, } \\
\text { nuclear alterations (nuclear vesiculation, anisonucleosis, binucleation), hydropic } \\
\text { degeneration and large areas of necrosis. Vascular congestion and fibrosis were } \\
\text { also observed. The study has confirmed the phenomenon of counterfeit } \\
\text { preparation for treatment of erectile dysfunction as the investigated product has } \\
\text { been shown to lack active sildenafil despite being marketed as a sildenafil product. } \\
\text { In addition, the study has pointed out the potential hepatotoxicity of } \\
\text { anthraquinone derivatives. }\end{array}$ \\
\hline
\end{tabular}

Introduction

Erectile dysfunction is prevalent worldwide. This dysfunction is associated with increased use of erectile enhancers. The market is full of counterfeit and adulterants (El Amrawy et al., 2016). Several factors

\footnotetext{
(I) Pathology Department, Faculty of Medicine, Assiut University, Egypt.

(2)Forensic Medicine and Clinical Toxicology Department, Faculty of Medicine, Assiut University, Egypt.
}

contribute to the development of the illicit market, such as low legal enforcement, high economic reward, and easy distribution of illicit drugs through the internet without supervision. In addition, embarrassment regarding erection dysfunction leads patients to avoid seeking professional medical visits (Chiang et al., 2017).

Between years of 2004 and 2008, 35.8 million illicit sildenafil tablets were confiscated in European countries. It was reported that 0.6 to 2.5 million men are using illicit sildenafil products compared to 
approximately 2.5 million of legal sildenafil users (Jackson et al., 2010).

In the United Kingdom, analysis of 2,383 seized samples of counterfeit sildenafil revealed that only $10 \%$ contained the same concentrations of active sildenafil that were advertised on the drug packaging (Stecher et al., 2010).

Illicit and counterfeit sildenafil from various countries were reported to contain different adulterants as amphetamine, caffeine, paracetamol, metronidazole, quinine, clomiphene, chloramphenicol, gammaaminobutyric acid, and yohimbine. The presence of unknown ingredients and impurities may lead to serious adverse effects and drug-drug interactions. Beside variation of dose and mislabeling may lead to unintentional toxicity due to overdose (Jackson et al., 2010). Furthermore, patients with contraindications to the use of sildenafil can consume products claiming to contain only natural substances (Eysenbach, 1999).

The aim of this study is to elucidate the various contents and concentration of sildenafil in a cheap illicit erection enhancer preparation available in local markets and to evaluate its potential toxic effects on the liver.

\section{Material and Methods}

An illicit erection/potency enhancer tablets carrying the name of "hard on" alleging to contain $130 \mathrm{mg}$ of sildenafil/tablet was analyzed. Analysis was conducted by Gas Chromatography-Mass Spectrometric (GC-MS 7890A-5975B) at Analytical Chemistry Unit, Faculty of Science, Assiut University, Egypt. Chromatographic separation was conducted by Agilent Technologies Gas Chromatograph (Model 7890A) equipped with temperature programming capability, split less injector, capillary column (Agilent DB-5ms), Mass Quadrupole Spectrometry detector Model 5975B was used. Measuring peak areas was performed by using a computer data system (MSD Chem Station E.0201.1177).

Oven Program: $40{ }^{\circ} \mathrm{C}$ for $2 \mathrm{~min}$ then 10 ${ }^{\circ} \mathrm{C} / \mathrm{min}$ to $150{ }^{\circ} \mathrm{C}$ for $3 \mathrm{~min}$ then $10{ }^{\circ} \mathrm{C} / \mathrm{min}$ to $220{ }^{\circ} \mathrm{C}$ for 6 min then $15{ }^{\circ} \mathrm{C} / \min$ to $280{ }^{\circ} \mathrm{C}$ for $15 \mathrm{~min}$.

Run time: 48 min and 2 min (Post Run) 260 ${ }^{\circ} \mathrm{C}$.

Flow Program: $0.5 \mathrm{~mL} / \mathrm{min}$ for $10.9 \mathrm{~min}$ then $1 \mathrm{~mL} / \mathrm{min}$ per min to $1 \mathrm{~mL} / \mathrm{min}$ for $30 \mathrm{~min}$.

The same preparation was administered via oral route to male mice for 8 weeks. Thirty male adult mice weighing 20 - 30 grams were maintained under optimal laboratory conditions. Feed and water were provided for ad- libitum consumption. All groups were exposed to the main two stages of the experiment period as follows; the first 2 weeks were the pre-treatment period for acclimatization, followed by 8 weeks of per oral administration. The animals were divided into 3 groups (each group containing 10 mice).

- The first group: used as the control; 10 mice received nothing except distilled water.

- The second group (therapeutic dose): received the preparation dissolved in distilled water at a dose equivalent to human therapeutic dose $(8.13 \mathrm{mg} / \mathrm{Kg} /$ day) calculated according to Paget and Barnes (1964).

- The third group (toxic dose): received the preparation dissolved in distilled water at a dose of $50 \mathrm{mg} /$ animal/day $\left(1 / 10^{\text {th }}\right.$ the minimal lethal dose $)$ (Badwan et al., 2001). 
At the end of the experiment, liver tissues were excised from the sacrificed animals. Representative sections from the liver tissues were fixed in $10 \%$ buffered formalin and then processed for embedding in paraffin wax by routine protocols. After that, 5-mmthick sections were cut and were stained with hematoxylin \& eosin stain, periodic acidSchiff (PAS) (to assess the glycogen content of the hepatocytes) and Masson's Trichrome stain (to assess the extent of fibrosis) (Sajjarattul et al., 2016). Haematoxylin and Eosin (H\&E) stained liver sections were evaluated for liver injuries including hydropic degeneration, nuclear alterations, vascular congestion, inflammation, necrosis, and fibrosis. The lesions were scored as: $0=$ normal, $1=$ mild $(1 \%$ to $30 \%), 2=$ moderate $(31 \%$ to $70 \%)$ and $3=$ severe $(>70 \%)$, according to the percentages of tissues affected.

Statistical analysis: Data was analyzed using SPSS software version 22. Data was expressed as mean \pm Standard deviation (SD), $\mathrm{p}$ value $<0.05$ was considered significant.
The study was conducted after ethical approval (number 17300302) according to the Guidelines of the National Institute of Health for Animal Care followed within the Faculty of Medicine, Assiut University, according to referenced authority (ILAR, 2011).

\section{Results}

Analysis of the tablets by GC-MS demonstrated the following ingredients: 1Bromo-2,4-dimethoxyanthrquinone, N-(4hydroxyphenyl)-acetamide, N-Trichloroacetyltryptamine, 26-Nor-5-cholesten-3, beta,ol-25one, Bis(2-ethylhexyl) phthalate, Dibutyl Phthalate, Hexadecanoic acid, Hexatriacontane, Isobutyl Phthalate, Octadecanoic acid, Octadecanoic acid ethyl ester, Phytane, Squalane and Sucrose octaacetate. Retention time and peak area for each compound are demonstrated in table (1). The chromatogram is shown in figure (1).

Table (1): Chemical compounds identified in the tablets extract by GC-MS.

\begin{tabular}{|l|l|l|}
\hline \multicolumn{1}{|c|}{ Name of compound } & Retention time (minute) & PA (peak area) \% \\
\hline 1-Bromo-2,4-Dimethoxyanthrquinone & 35.641 & 0.486 \\
\hline N-(4-hydroxyphenyl)-Acetamide & 20.382 & 2.909 \\
\hline N-Trichloroacetyl-Tryptamine & 33.741 & 0.340 \\
\hline 26-Nor-5-cholesten-3, beta,ol-25-one & 39.413 & 0.193 \\
\hline Bis(2-ethylhexyl) phthalate & 32.441 & 0.422 \\
\hline Dibutyl Phthalate & 23.25 & 0.084 \\
\hline Hexadecanoic acid & 23.541 & 0.224 \\
\hline Hexatriacontane & 19.968 & 0.230 \\
\hline Isobutyl Phthalate & 22.148 & 0.086 \\
\hline Octadecanoic acid & 23.675 & 16.558 \\
\hline Octadecanoic acid, ethyl ester & 26.741 & 0.679 \\
\hline Phytane & 22.603 & 0.051 \\
\hline Squalane & 35.093 & 1.374 \\
\hline Sucrose Octaacetate & 37.728 & 62.414 \\
\hline
\end{tabular}




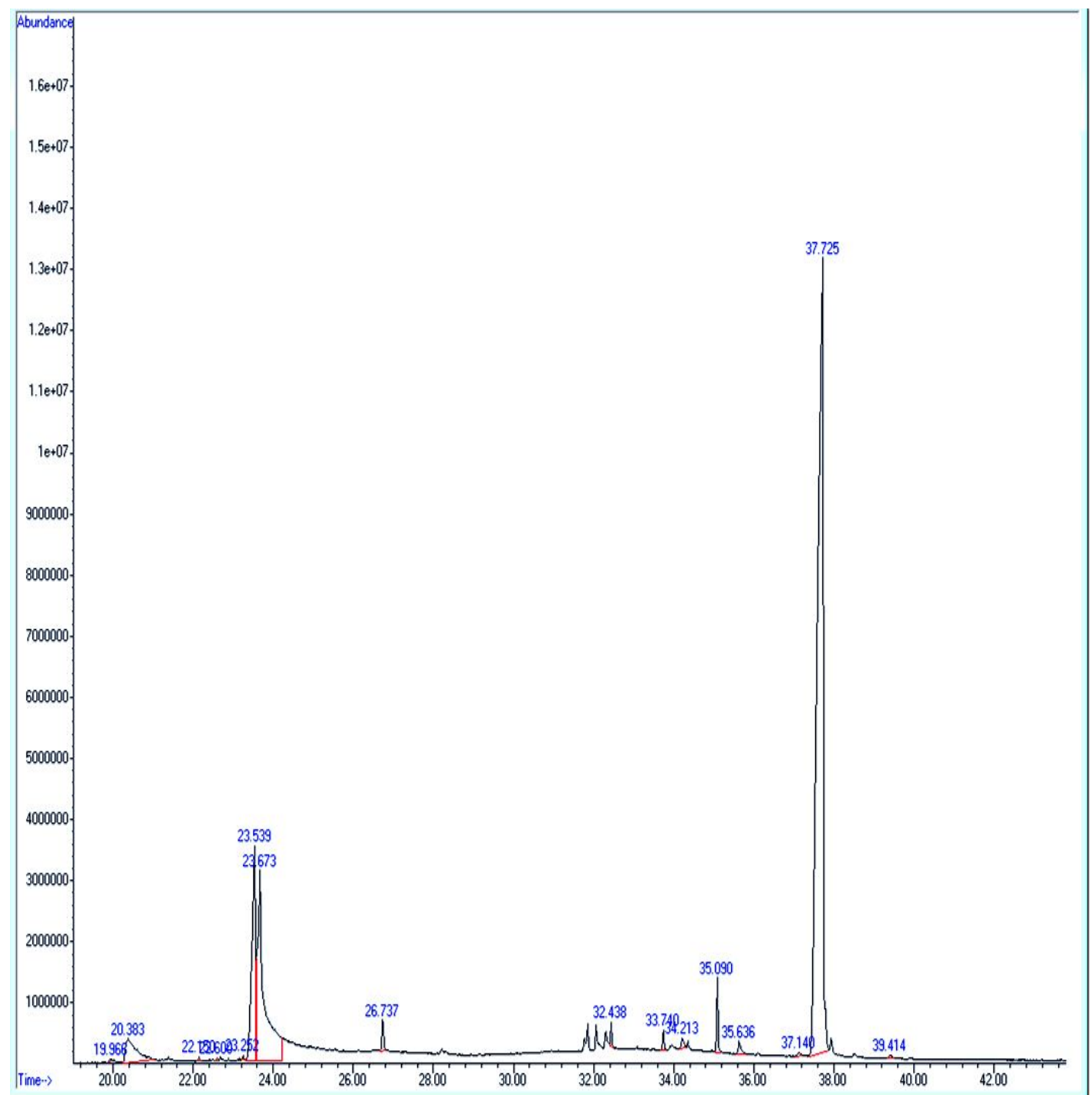

Fig. (1): Chromatogram of chemical ingredients of an illicit erection enhancer (Hard on tablet).

In the normal control group, the liver tissues showed preserved normal hepatic architecture having distinct plates of the hepatocytes, sinusoidal spaces, and a central vein without any pathological changes (Figures 2A\&B). Masson's Trichrome staining of liver sections of the normal control group showed no collagen deposition (Figure 2C). PAS-stained sections showed normal glycogen content of the hepatocytes which appeared as deeply red purple-colored PAS-positive inclusions densely located inside the cytoplasm (Figure 2D). 


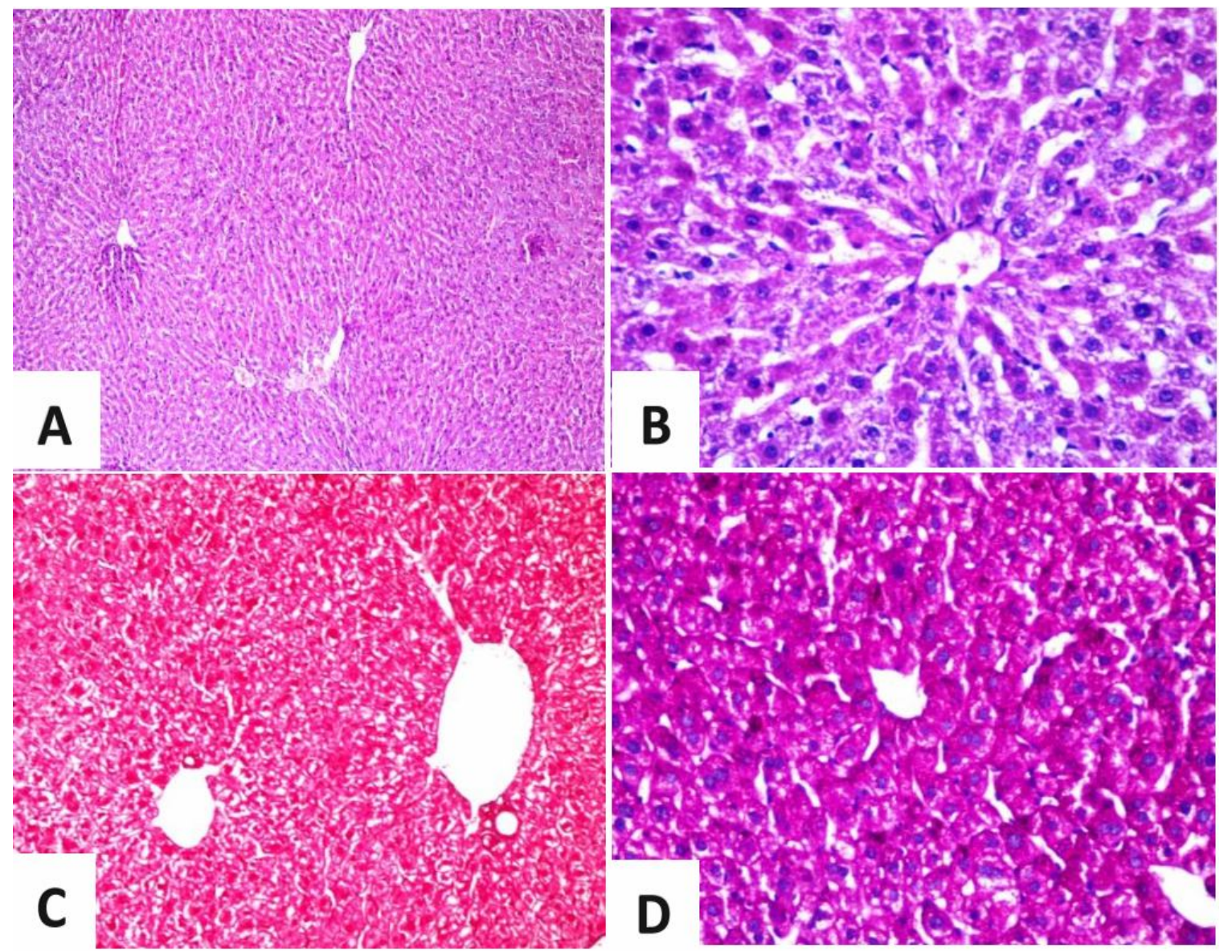

Fig. (2): Photomicrographs of representative liver sections from the normal control group. Hematoxylin and Eosin stained sections showing preserved liver architecture without any pathological changes (A; x100 \& B; x400). Masson's Trichrome stain showing no collagen deposition $(\mathrm{C} ; \mathrm{x} 400)$. PAS-stain showing normal glycogen content of the hepatocytes $(\mathrm{D} ; \mathrm{x} 400)$.

Hepatic tissues from the therapeutic dose group showed variable histopathologic alterations in the form of lobular inflammation (Figure 3A), mild hydropic degeneration (Figure 3B.), mild vascular congestion (Figure 3B), kupffer cell hyperplasia (Figure 3B). Nuclear alterations in the form of nuclear vesiculation, anisonucleosis (Figure 3C), binucleation (Figure 3A) were also observed. Occasional parenchymal necrosis was focally seen (Figure 3C). Focal areas of perivenular and perisinusoidal fibrosis were detected
(Figure 3D). Masson's Trichrome staining of liver sections of the therapeutic dose group showed perisinusoidal and perivenular fibrosis (Figure 3E). Compared with the control liver, partial glycogen depletion was observed in the hepatocytes by PAS stain (Figure 3F). The score of liver injuries in the therapeutic dose group was summarized in table (2). The mean score of liver injuries in the therapeutic dose group was significantly higher than that of the normal control group $(p=0.002)$. 


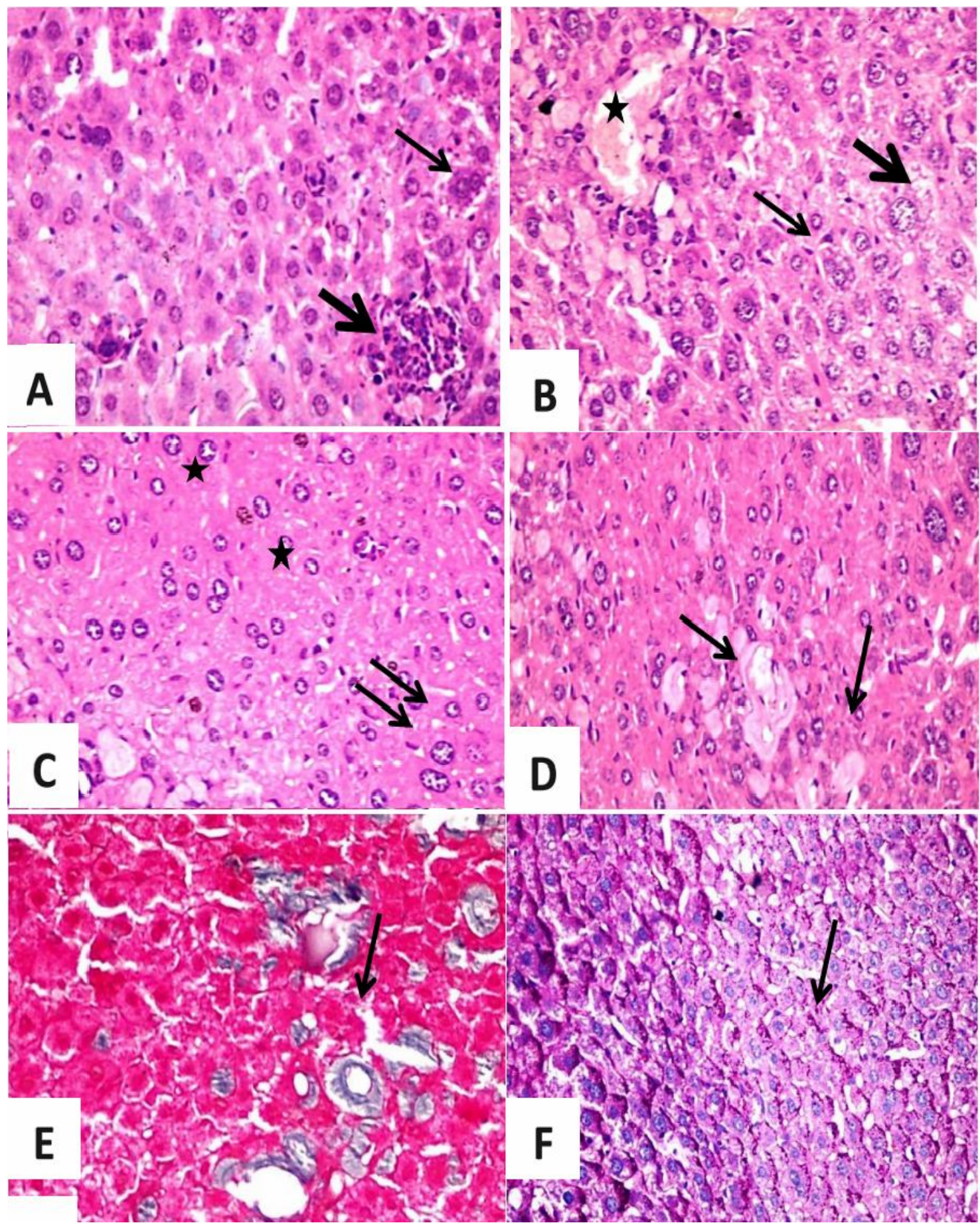

Fig. (3): Photomicrographs of representative liver sections from the therapeutic dose group. Hematoxylin and Eosin stained sections show: lobular inflammation (thick arrow) and binucleation (thin arrow) (A; x400). Mild hydropic degeneration (thick arrow), mild vascular congestion (star) and kupffer cell hyperplasia (thin arrow) $(\mathrm{B} ; \mathrm{x} 400)$. Nuclear vesiculation, anisonucleosis (arrow) and necrosis (star) (C; x400). Perivenular and perisinusoidal fibrosis (arrow) (D; x400). Masson's Trichrome stain showing perivenular and perisinusoidal fibrosis (arrow) (E; $\mathrm{x} 400)$ ). PAS-stain showing partial depletion of the glycogen within the hepatocytes (arrow) (F; x400). 
Table (2): Mean score of liver injuries of the study groups (30 mice).

\begin{tabular}{|l|c|c|c|}
\hline & $\begin{array}{c}\text { Normal Control } \\
\text { group } \\
\mathbf{( 1 0} \text { mice })\end{array}$ & $\begin{array}{c}\text { Therapeutic dose } \\
\text { group } \\
\mathbf{( 1 0} \text { mice })\end{array}$ & $\begin{array}{c}\text { Toxic dose } \\
\text { group } \\
(\mathbf{1 0} \text { mice })\end{array}$ \\
\hline Type of liver injury & Mean & Mean \pm SEM & Mean \pm SEM \\
\hline Hydropic degeneration & 0 & $1.4 \pm 0.16$ & $2.2 \pm 0.24$ \\
\hline Nuclear alterations & 0 & $1.6 \pm 0.22$ & $1.8 \pm 0.24$ \\
\hline Necrosis & 0 & $1.4 \pm 0.16$ & $2.6 \pm 0.16$ \\
\hline Inflammation & 0 & $1.3 \pm 0.15$ & $1.6 \pm 0.16$ \\
\hline Vascular congestion & 0 & $1.5 \pm 0.22$ & $2.5 \pm 0.16$ \\
\hline Fibrosis & 0 & $0.8 \pm 0.24$ & $1.2 \pm 0.24$ \\
\hline Mean score of liver injuries & 0 & $1.33 \pm 0.11^{*}$ & $1.98 \pm 0.22 *, \neq$ \\
\hline
\end{tabular}

SEM: Standard error of mean, ${ }^{*} p$ value $<0.05$ (significant) when compared to the normal control group. ${ }^{7} p$ value $<0.05$ (significant) when compared to the therapeutic dose group.

Significant histopathologic changes were observed in the hepatic tissues from the toxic dose group. The mean score of liver injuries in the toxic dose group was significantly higher than that of the normal control group $(\mathrm{p}$ $=0.002)$ and therapeutic dose group $(\mathrm{p}=$ 0.045). These changes include severe lobular inflammation (Figure 4A), kupffer cell hyperplasia (Figure 4B), nuclear alterations (nuclear vesiculation, anisonucleosis (Figure 4B), binucleation (Figure 4C), more prominent hydropic degeneration (Figure 4C) and large areas of necrosis (Figure 4D). Severe congestion of the central vein (Figure 4E) and portal vessels (Figure 4F) were also observed. Portal, perivenular and perisinusoidal fibrosis were more prominent than that detected in the toxic dose group (Figure 4 E \& F). Masson's Trichrome staining showed perisinusoidal and perivenular fibrosis (Figure 4G). Compared with the control liver, marked reduction in periodic acid Schiff (PAS) reaction was observed in many hepatocytes (Figure 4H). The score of liver injuries in the toxic dose group was summarized in table (2). 

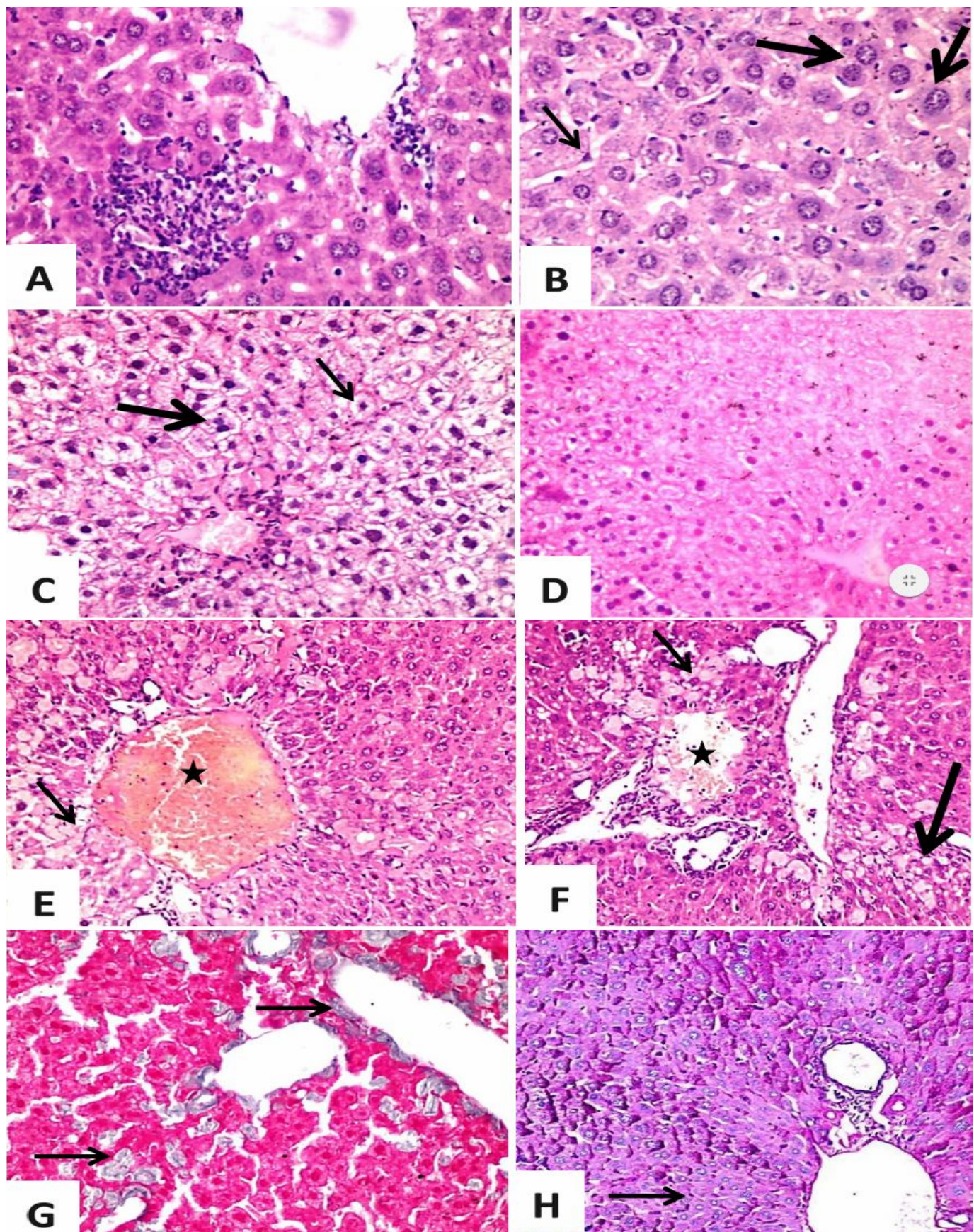

B
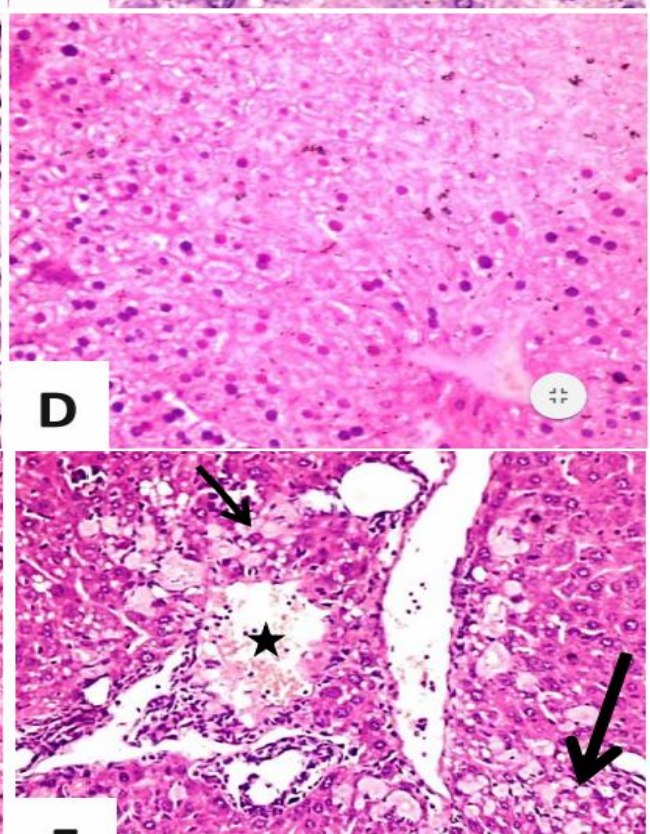

F

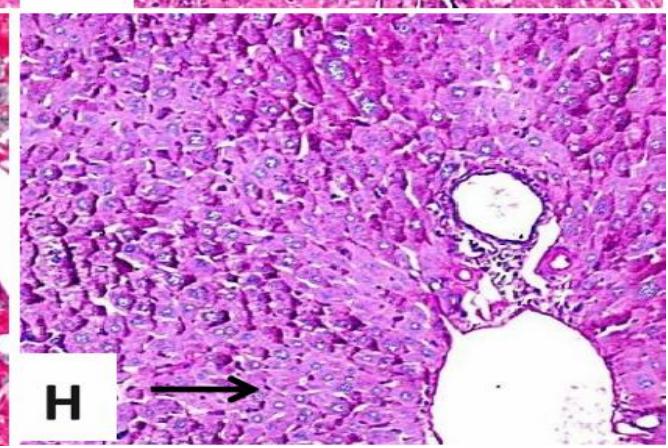

Fig. (4): Photomicrographs of representative liver sections from the toxic dose group. H\& E stained sections show: severe lobular inflammation (A; x400). Kupffer cell hyperplasia (thin arrow), nuclear vesiculation, anisonucleosis (thick arrow) (B; $\mathrm{x} 400)$. Severe hydropic degeneration (thin arrow) and binucleation (thick arrow) $(C ; x 400)$. Large area of necrosis $(\mathrm{D} ; \mathrm{x} 400)$. Vascular congestion (star) and perivenular fibrosis (thin arrow) $(\mathrm{E}$; $\mathrm{x} 400)$. Portal (thin arrow) and perisinusoidal fibrosis (thick arrow), congestion of the portal vessels (star) (F; x400). Masson's Trichrome stain showing perivenular and perisinusoidal fibrosis (arrow) (G; $\mathrm{x} 400)$. PAS-stain showing marked depletion of the glycogen within the hepatocytes (arrow) $(\mathrm{H} ; \mathrm{x} 400)$. 


\section{Discussion}

The production of counterfeit and illicit drugs is a worldwide problem that constitutes a serious health risk. A major proportion of the counterfeit medication market is attributable in part to phosphodiesterase type 5 inhibitor pharmaceutical preparations for erectile dysfunction (Jackson et al., 2010). Sildenafil citrate is the first drug to be approved for the treatment of this sexual disorder. Its mechanism of action is by blocking phosphodiesterase type 5 enzyme (Pereira et al., 2014). This has a hepatoprotective effect via hemodynamic changes in the liver (Halverscheid et al., 2009). Sildenafil also increases levels of the c-GMP, which is an intracellular mediator of the nitric oxide. Nitric oxide causes relaxation of the vasculature hence, increasing the blood flow (Tang et al., 2015).

The present results revealed that analysis of an illicit erection enhancer oral preparation claimed to contain $130 \mathrm{mg}$ sildenafil citrate by GC-MS demonstrated that the tablets have no sildenafil citrate among its ingredients. The tablets contained 1-Bromo2,4-dimethoxyanthrquinone, N-(4-hydroxyphenyl) -acetamide, N-Trichloroacetyltryptamine, 26-Nor-5-cholesten-3, beta,ol-25one, Bis(2-ethylhexyl) phthalate, Dibutyl Phthalate, Hexadecanoic acid, Hexatriacontane, Isobutyl Phthalate, Octadecanoic acid, Octadecanoic acid ethyl ester, Phytane, Squalane and Sucrose octa-acetate.

The largest component of the tablet was Sucrose octaacetate. It was reported that Sucrose octaacetate has potential applications as a foaming agent, emulsion stabilizer, and as an antifungal agent in pharmaceutical and cosmetic preparations (Petkova et al., 2017). Squalane which is another ingredient of the analyzed tablet is stable transparent oil that was identified as natural component of human sebum and used safely in cosmetic preparations (Christian, 1982). Squalane is obtained by molecular distillation of shark liver oil. It is also used as an ingredient of suppositories, and as a carrier of lipid-soluble drugs (Popa et al., 2015).

$\mathrm{N}$-(4-hydroxyphenyl) acetamide is one of several chemical names for the analgesic acetaminophen. Acetaminophen was detected previously as an adulterant in a traditional aphrodisiac preparation by thin layer chromatography (Septiani and Damayanti, 2015). Acetaminophen is a safe drug used to relieve pain. However, it is commonly implicated in accidental and suicidal overdoses leading to severe hepatic injury (Ramachandran and Jaeschke, 2019).

26-Nor-5-cholesten-3, beta,ol-25-one is a steroid compound with antimicrobial, antiinflammatory, antioxidant, hepatoprotective, hypoglycemic, antipyretic and estrogenic activities (Meenakshi et al., 2012). Bis (2ethylhexyl) phthalate, Dibutyl Phthalate, and Isobutyl Phthalate were detected in the tablets in the present study. Phthalates are a group of synthetic chemicals, which are used mainly in polymerization industries like footwear, toys and medical devices. Non-polymer uses include ink, paint and adhesive industries. Pharmaceutical products may also have phthalate plasticizers in their coatings (IARC, 2000). Hexadecanoic acid (Palmitic acid) has the property of antioxidant activity (Sudha et al., 2013). Hexadecanoic acid is used in oral pharmaceutical preparation and is generally regarded as a nontoxic compound (CIR, 1987). Octadecanoic acid is a fatty acid with potent antifungal, antimicrobial and antibacterial activities (Kumar and Rajakumar, 2016). Octadecenoic acid, ethyl ester was reported to have perfumery activity (Ross, 2003). Phytane is a compound derived from the chlorophyll pigment that absorbs and transfers light (Rasmussen et al., 2008). Phytane was detected in a wide range of crude oils and microbial colonies (Barber et al., 2001). 
Tryptamine derivatives are psychoactive substances with a long history of licit and illicit use (Sanders et al., 2008). Well-known tryptamines, such as LSD and psilocybin are thoroughly researched (Griffiths et al., 2006). While little literature is available regarding the potential toxicity of the new tryptamine derivatives (Araújo et al., 2015). Some synthetic tryptamine derivatives are reported to produce similar effects to those produced by psilocin. Those effects include visual hallucinations, euphoria, exaggerated tactile sensations, feeling of flushing, and increased libido (Dargan and Wood, 2013).

Anthraquinones are an important class of naturally occurring biologically active compounds produced by different plants of various families (Yeap et al., 2015). Anthraquinones are found in rhubarb, Senna, Cascara sagrada, buckhorn, and aloe (Chan and Lin, 2009). Anthraquinone and its derivatives are a group of quinoids that have wide chemical diversity. These derivatives recently gained great attention of the pharmaceuticals industry and other fields as clothes dyes, and food colorants (Fouillaud et al., 2016).

Anthraquinones are mainly used as laxatives (Anton and Haag-Berrurie, 1980). A recent study reported that anthraquinones and anthraquinone glycoside could be novel drugs for treating erectile dysfunction (Khanh et al., 2018).

The current study showed that administration of the erection enhancer tablets to male mice (for 8 weeks daily) in a dose equivalent to the human therapeutic dose of sildenafil citrate caused histopathological changes in the liver. Those changes included mild hydropic degeneration, vascular congestion, and kupffer cell hyperplasia. Nuclei showed vesiculation, anisonucleosis, binucleation. Focal areas of perivenular and perisinusoidal fibrosis were detected. The mean score of liver injuries was significantly higher than that of the normal control group.

The present study also showed significant histopathologic changes in the liver of mice that were administered the erection enhancer in $1 / 10^{\text {th }}$ the lethal dose and the mean score of liver injuries was significantly higher than that of the group administered the therapeutic dose. These changes included severe lobular inflammation, kupffer cell hyperplasia, nuclear alterations (nuclear vesiculation, anisonucleosis, binucleation, more prominent hydropic degeneration and large areas of necrosis. Severe vascular congestion, portal, perivenular and perisinusoidal fibrosis were observed. Those changes could be attributed to the presence of 1Bromo-2,4-dimethoxyanthraquinone in the studied preparation.

Exposure of the liver to unusual amounts of toxic metabolites of anthraquinone glycosides was reported to cause acute hepatic failure in a 52-year-old woman who had consumed, for more than 3 years, a herbal tea containing dry senna fruits (Vanderperren et al., 2005).

An experimental animal study reported that anthraquinones might be responsible for the hepatotoxicity of Polygonum multiflorum plant (Zhang et al., 2018). In rats, Polygonum multiflorum plant caused liver injury in the form of cell swelling, ballooning of degenerating cells, and focal infiltration of inflammatory cells (Lin et al., 2017).

A two-year study, conducted by National Toxicology Program (2001) on one of the main anthraquinone derivatives of rhubarb, demonstrated its hepatotoxic effects on rats and mice. The laxative herb Cascara sagrada containing anthracene glycosides was also reported to cause cholestatic hepatitis through an unknown mechanism (Nadir et al., 2000). 


\section{Conclusion}

In the present study, identification of pharmaceutically active ingredients of an illicit erection enhancer tablets (Hard on) sold in local markets as $130 \mathrm{mg}$ sildenafil citrate revealed several ingredients with no sildenafil citrate content. The tablets contained a potential hepatotoxic anthraquinone derivative. As the anthraquinone derivative is detected in a compound formulation, together with acetaminophen. Consequently, the hepatoxic effects of the product cannot be simply attributed to anthraquinone derivative alone. The present results establish the phenomenon of drug counterfeiting, which increased in the last decades and poses a health risk. It is recommended to increase and enforce more surveillance policies on the pharmaceutical market.

\section{References}

Anton, R. and Haag-Berrurier, M. (1980): "Therapeutic use of natural anthraquinone for other than laxative actions". Pharmacology, 20:104-112.

Araújo, AM.; Carvalho, F.; Bastos, M.L.; et al. (2015): "The hallucinogenic world of tryptamines: an updated review". Arch Toxicol., 89(8):1151-1173.

Badwan, A.; Nabulsi, L.; Al Omari, M.; et al. (2001): Sildenafil Citrate. In: Profiles of drug substances, Excipients and related methodology. Brittain, $\mathrm{H}$. (Ed), $1^{\text {st }}$ ed. Academic Press, USA, P.P.339-376.

Barber, K.J.; Grice, K.; Bastow, T.P.; et al. (2001): "The identification of crocetane in Australian crude oils". Organic Geochemistry, 32:943-947.

Chan, K. and Lin, T.X. (2009): Treatments used in complementary and alternative medicine. In: Side Effects of Drugs
Annual. Sidhartha, R. (Ed.), $1^{\text {st }}$ ed. Elsevier, Amsterdam, Netherlands, P.P. 745-756.

Chiang, J.; Yafi, F.A; Dorsey, P.J.; et al. (2017): "The dangers of sexual enhancement supplements and counterfeit drugs to "treat" erectile dysfunction". Transl. Androl. Urol., 6(1):1219.

Christian, M. (1982): "Final report on the safety assessment of squalane and squalene". J. Am. Coll. Toxicol., 1(2): $37-56$.

Cosmetic Ingredient Review "CIR" (1987): Final report of the safety assessment for oleic acid, lauric acid, palmitic acid, myristic acid, stearic acid. Prepared by the Expert Panel of the Cosmetic Ingredient Review, Washington D.C., 3:321-401.

Dargan, P.I and Wood, D.M. (2013): Novel Psychoactive Substances: Classification, Pharmacology and Toxicology. $1^{\text {st }}$ ed. Academic Press, London, UK, P.P. 393409.

El Amrawy, F.; ElAgouri, G.; Elnoweam, O.l.; et al. (2016): "Adulterated and counterfeit male enhancement nutraceuticals and dietary supplements pose a real threat to the management of erectile dysfunction: A Global Perspective”. J. Diet Suppl., 13:1-34.

Eysenbach, G. (1999): “Online prescribing of sildanefil (Viagra) on the world wide web”. J. Med. Internet Res., 1(2):E10.

Fouillaud, M.; Venkatachalam, M.; GirardValenciennes, E.; et al. (2016): "Anthraquinones and derivatives from marine-derived fungi: structural diversity and selected biological activities". Mar. Drugs., 14(4): 64.

Griffiths, R.R.; Richards, W.A.; McCann, U.; et al. (2006): "Psilocybin can occasion 
mystical-type experiences having substantial and sustained personal meaning and spiritual significance". Psychopharmacology

(Berl)., 187(3):268-283.

Halverscheid, L.; Deibert, P.; Schmidt, R.; et al. (2009): "Phosphodiesterase-5 inhibitors have distinct effects on the hemodynamics of the liver". BMC Gastroenterol., 18:9:69.

Institute of Laboratory Animal Resources (IARC) (2000): "Some Industrial Chemicals". IARC Monogr. Eval. Carcinog. Risk Hum., 77:41-59.

Institute of Laboratory Animal Resources (ILAR) (2011): Guide for the Care and Use of Laboratory Animals. $8^{\text {th }}$ ed. National Academies Press, Washington, D.C., P.P. 41-103.

Jackson, G.; Arver, S.; Banks, I.; and Stecher, VJ. (2010): "Counterfeit phosphodiesterase type 5 inhibitors pose significant safety risks". Int. J. Clin. Pract., 64:497-504.

Khanh, P.N.; Huong, T.T.; Spiga, O.; et al. (2018): "In silico screening of anthraquinones from Prismatomeris memecyloides as novel phosphodiesterase type-5 inhibitors (PDE-5Is)". Rev. Int. Androl., 16(4):147-158.

Kumar, D.G. and Rajakumar, R. (2016): "GAS Chromatography mass Spectrometry analysis of bioactive components from the ethanol extract of Avicennia Marina leaves". Innovare Journal of Science, 4 (4): 9-12.

Lin, L.; Li, H.; Lin, H.; et al. (2017): "Application of iTRAQ - based quantitative proteomics approach to identify deregulated proteins associated with liver toxicity induced by polygonum multiflorum in rats". Cell Physiol. Biochem., 43(5):2102-2116.

Meenakshi, V.K.; Gomathy, S.; and Chamundeswari, K.P. (2012): "GC - MS analysis of the simple ascidian microcosmus exasperatus heller, 1878". Int. J. Chem. Tech. Res., 4(1):55-62.

Nadir, A.; Reddy, D.; and Van Thiel, D.H. (2000): "Cascara sagrada-induced intrahepatic cholestasis causing portal hypertension: case report and review of herbal hepatotoxicity". Am. J. Gastroenterol., 95: 3634-3637.

National Toxicology Program (2001): "Technical report on the toxicology and carcinogenesis studies of emodin in F344/N rats and B6C3F1 mice". Natl. Toxicol. Program Tech. Rep. Ser., 493:1278.

Paget, G.E. and Barnes, J.M., (1964): Evaluation of Drug Activities, in: Pharmacometrics. Lawrence, D.R. and Bacharach, A.L. (Eds), $1^{\text {st }}$ ed., Academic press. New York, P.P. 161.

Pereira, T.; Júnior, A.Q.O.; Ortiz, R.; et al. (2014): "Viagra (R) and Cialis (R) blister packaging fingerprinting using Fourier transform infrared spectroscopy (FTIR) allied with chemometric methods". Anal. Methods., 6: 2722-2728.

Petkova, N.; Vassilev, D.; Arabadzhieva, R.; et al. (2017): "Green synthesis of sucrose octaacetate and characterization of its physicochemical properties and antimicrobial activity". Chem. Biochem. Eng. Q., 31:395-402.

Popa, O.; Băbeanu, N.; Popa, I.; et al. (2015): "Methods for obtaining and determination of squalene from natural sources". BioMed. Res. Int., 15:1-16. 
Ramachandran, A. and Jaeschke, H. (2019): "Acetaminophen Hepatotoxicity". Semin. Liver Dis., 39(2):221234.

Rasmussen, B.; Fletcher, I.R.; Brocks, J.J. and Kilburn, M. R. (2008): "Reassessing the first appearance of eukaryotes and cyanobacteria”. Nature, 455:1101-1104.

Ross, I. A. (2003): Medicinal plants of the world. Vol.1. Chemical constituents, traditional and modern medicinal uses. Humana press Inc., Totowa, P. 455.

Sajjarattul, N.A.; Hamzah, H. and Rosly, M.S. (2016): "Blood profiles and histopathological changes of liver and kidney tissues from male sprague dawley rats treated with ethanol extracts of Clinacanthus nutans Leaf'. J. Clin. Toxicol., 6(6):1-10.

Sanders, B.; Lankenau, S. E.; Bloom, J. J.; et al. (2008): "Research chemicals: tryptamine and phenethylamine use among high-risk youth". Subst. Use Misuse, 43(3-4): 389-402.

Septiani, R. and Damayanti, S. (2015): "Simultaneous identification of caffeine, acetaminophen, sildenafilcitrate, tadalafil and vardenafil $\mathrm{HCl}$ in aphrodisiac traditional herbal medicines by Thin Layer ChromatographyDensitometry". Der. Pharma. Chemica., 7(5):335-341.

Stecher, V.; Jackson, G.; Banks, I.; et al. (2010): "Analysis of pharmaceuticals seized by authorities in the united kingdom for suspicion of being counterfeit VIAGRA ® (Sildenafil Citrate)". AM. J. Men's Health, 7:321-321.

Sudha, T.; Chidambarampillai, S.; and Mohan, V.R. (2013): "GC-MS analysis of bioactive components of aerial parts of Fluggea leucopyrus Willd. (Euphorbiaceae)". J. Appl. Pharm. Sci., 3 (5):126-130.

Tang, W.H.; Zhuang, X.J.; Ma, L.L.; et al. (2015): "Effect of sildenafil on erectile dysfunction and improvement in the quality of sexual life in China: a multicenter study". Int. J. Clin. Exp. Med., 8(7):11539- 11543.

Vanderperren, B.; Rizzo, M.; Angenot, L.; et al. (2005): "Acute liver failure with renal impairment related to the abuse of senna anthraquinone glycosides". Ann. Pharmacother., 39(7-8):1353-1357.

Yeap, S.; Akhtar, M.N.; Lim, K.L.; et al. (2015): "Synthesis of an anthraquinone derivative (DHAQC) and its effect on induction of $\mathrm{G} 2 / \mathrm{M}$ arrest and apoptosis in breast cancer MCF-7 cell line". Drug Des. Devel. Ther., 17(9):983-992.

Zhang, M.; Lin, L.; Lin H.; et al. (2018): "Interpretation the hepatotoxicity based on pharmacokinetics investigated through oral administrated different extraction parts of Polygonum multiflorum on Rats". Front Pharmacol., 25(9):1-13. 


\title{
تحليل كروماتوجرافيا الفاز ـ مطياف الكتلة لعقار سيلدينافيل مزيف وسميته المحتملة على الكبد في الفئران
}

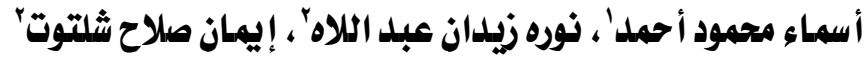 \\ قسم الباثولوجيا، كلية الطب، جامعة أسيوط'

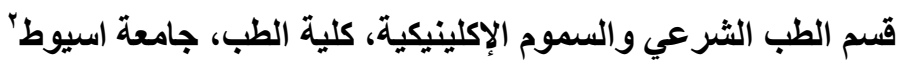

تز ايدت التجارة غير القانونيـة للأدويـة المزيفة الخاصـة بعلاج ضـف الانتصاب بشكل ملحوظ في العقد

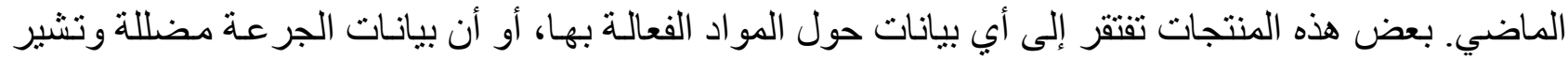
إلى احتو ائها على مو اد طبيعية فقط. تهدف هذه الدراسة إلى معرفة مكونات أقر اص أحد المنتجات الدوائية غير

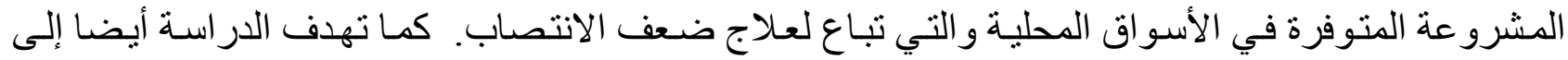
معرفة تركيز السيلدينافيل في هذه الأقر اص وتقييم آثار هـا السامة المحتملـة على الكبد في الفئر ان. تم تحليل المستحضر بواسطة تحليل الغاز الكروماتوجر افي ذو الكتلة الطيفية (GC-MS). كما تم اعطاء نفس المستحضر بعد إذابته في ماء مقطر عن طريق الفم يوميأ لمدة ^ أسابيع للفئر ان الذكور للتحقق من آثاره على أنسجة الكبد. شملت الدر اسة ب مجمو عات تتكون كل مجمو عة من · ( فئر ان وقد تم اعطلاء مـاء مقطر للمجمو عـة الضابطة.

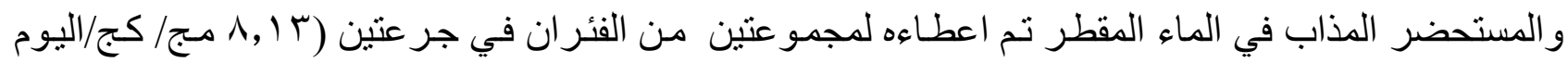

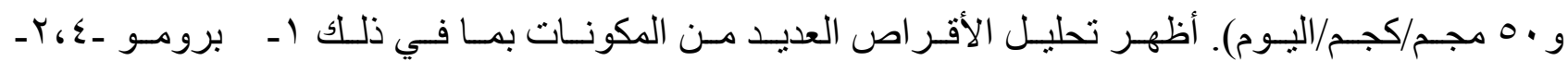

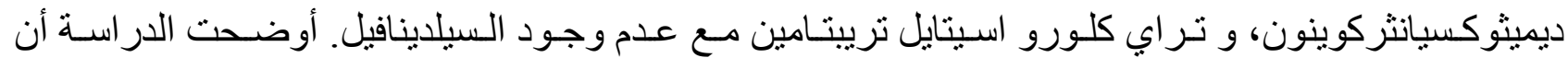
المستحضر تسبب في تغير ات نسيجية في كبد الفئران مقارنة بالمجمو عة الضابطة. تناسبت تلك التغير ات طرديـا

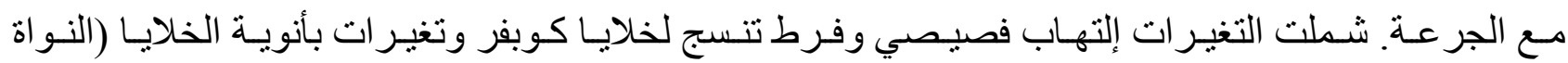
الحويصلية، ظهور خلايا ثنائية النواة وخلايا بدون نو اة)، و التنكس المـائي ومساحات كبيرة من النخر ـ ولوحظ وله أيضا احتقان الأوعية الدموية والتليف. الخلاصة: تؤكد الدر اسة على ظاهرة تجارة المستحضر ات المزيفة لعلاج

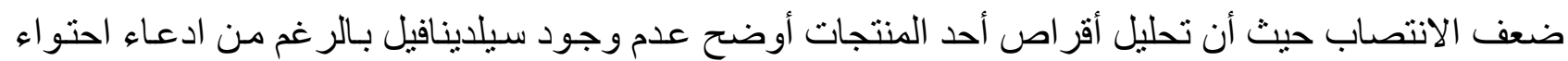

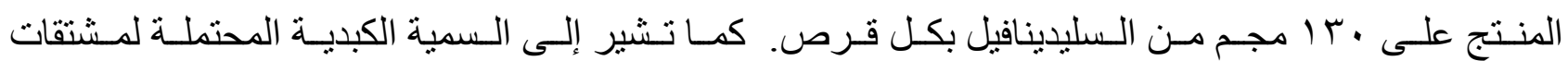
الأنثر كوينون. 